Creative Commons User License: CC BY-NC-ND

Abstracted by: EBSCOhost, Electronic Journals Service (EJS), Google Scholar, Journal Seek, Scientific Commons,

Food and Agricultural Organization (FAO), CABI and Scopus

http://eoi.citefactor.org/10.11226/v24i2
Journal of Agricultural Extension

Vol. 24 (2) April, 2020

ISSN(e): 24086851; ISSN(Print); 1119944X

http://journal.aesonnigeria.org

http://www.ajol.info/index.php/iae

Email: editorinchief@aesonnigeria.org

\title{
Institutional Factors Influencing Diary Farmers Participation in Formal and Informal Milk Markets in Maseru Urban, Lesotho, South Africa
}

https://dx.doi.org/10.4314/jae.v24i2.6

\section{Rantlo, Ashby Montoeli}

National University of Lesotho, Roma, Lesotho

Correspondence : am.rantlo@nul.Is; amontoeli@yahoo.co.uk. Mobil: +266 59134917

Tsoako, Molulela

National University of Lesotho, Roma, Lesotho

Email: tsoakomolulela@gmail.com Mobil: +266 22340601

\section{Muroyiwa, Brian}

National University of Lesotho, Roma, Lesotho

Email: b.muroyiwa@nul.Is. Mobil: +266 22340601

\section{Abstract}

The study assessed institutional factors influencing participation in milk markets in Maseru urban. Thirty (30) diary farmers were selected using structured questionnaires. Data were analysed using percentage and logit regression model. Results showed that dairy farmers (60\%) used formal market channels more than informal market channels (40\%). Market information (0.083), membership in organization and collective action (0.088), government support (0.036) and contractual agreements (0.034) influence participation in formal markets while social capital (0.036), path dependency (0.043), delayed payments (0.084) and distance to milk collection centres (0.054) influence participation in the informal markets. Advance payments should be introduced; institutional support system developed as well as the decentralisation of the milk collection centers or points.

Keywords: Market participation, institutional factors, milk markets, dairy farmers

\section{Introduction}

In the age of trade liberalization and globalisation, the world markets are increasingly being integrated (Rantlo, 2018). This implies that farmers in the developing world are more linked to consumers and corporations of the rich nations. Consequently, local farmers are facing increasing market competition, not only in international markets, but in local markets as well. In an effort to withstand the market pressures, agricultural markets are now transforming to a vertically coordinated structure (Goodwin and Gouldthorpe, 2014). Both the private and public sectors have made some adjustments in agricultural markets in order to survive competition resulting from market changes.

The Lesotho agricultural sector was deregulated in 1997, with the aim of creating an open and market-oriented environment for boosting the sector. Based on the Agricultural Marketing Act of 1996, government intervention in agricultural marketing through the use of control boards was ceased. This change resulted in smallholder 
Creative Commons User License: CC BY-NC-ND

Abstracted by: EBSCOhost, Electronic Journals Service (EJS), Google Scholar, Journal Seek, Scientific Commons,

Food and Agricultural Organization (FAO), CABI and Scopus
Journal of Agricultural Extension

Vol. 24 (2) April, 2020

ISSN(e): 24086851; ISSN(Print); 1119944X

http://journal.aesonnigeria.org

http://www.ajol.info/index.php/jae

Email: editorinchief@aesonnigeria.org

http://eoi.citefactor.org/10.11226/v24i2

farmers and other formerly deprived farmers in output markets being included in agricultural marketing (Ministry of Agriculture and Food Security, 2016). Although the policy is now oriented in favour of smallholder farmers, they still have to compete for markets with the already developed commercial sector. For this reason, their survival in the markets is still at stake. In output markets, smallholder farmers are often faced with difficulties in enforcing contracts and meeting stringent food safety norms, lack skills and are located in remote areas and mostly rely on middlemen. They are also faced with poor physical infrastructures and weak institutions in markets (Goodwin and Gouldthorpe, 2014).

Markets are important because they act as a mechanism for exchange. They are particularly important to the poor because their involvement in the use of markets results in co-ordination and allocation of resources, goods and services. In other words, markets are very important in reducing poverty and improving livelihoods of households. It follows that market participation is important amongst smallholder farmers because households derive benefits such as income and open opportunities for rural employment (Ramoroka, 2012). In addition, marketing activities such as processing, transportation and selling can provide employment for those willing to exit the farming sector. At the national level, Bairwa et al, (2014) identified that market participation is important both for sustainable agriculture and economic growth and for the alleviation of poverty and inequality. Unfortunately, smallholder farmers face difficulties in accessing markets, as a result, markets fail from effectively performing their duty. The barriers that hinder markets from serving the interests of smallholder farmers, giving special attention to institutional and technical factors cannot be neglected (Ministry of Agriculture and Food Security, 2016).

In Lesotho, smallholder farmers find it difficult to participate in commercial markets due to a range of institutional constraints. Factors such as poor infrastructure, lack of market transport, dearth of market information, insufficient expertise on grades and standards, inability to have contractual agreements and poor organisational support could hinder farmers from assessing markets, hence, commercialisation bottlenecks. According to Moturi et al., (2015), dairy farmers' choices of marketing channel are largely determined by different institutional factors.

Institutions are defined by Rantlo (2018) as rules of the game that facilitate coordination or govern relationships between individuals or groups. Sekoai and Rantlo (2016) divided institutions into formal and informal institutions. Institutional aspects and their role in marketing and economic development revolve around transaction costs, market information flows and the institutional environment. It is affirmed that smallholder farmers in developed rural economies lack adequate market information and contractual arrangements, lack lobbies in the legal environment and are not easily receptive to changes (Ferris et al, 2014). These factors result in high transaction costs, hence difficulties in formal market participation. Farmers prefer marketing channels where they incur low costs and that offers higher prices to maximize profits. Acocording to Jagwe (2012), when smallholder farmers are faced with high transaction costs, they will either stop 
Creative Commons User License: CC BY-NC-ND

Abstracted by: EBSCOhost, Electronic Journals Service (EJS), Google Scholar, Journal Seek, Scientific Commons,

Food and Agricultural Organization (FAO), CABI and Scopus

http://eoi.citefactor.org/10.11226/v24i2
Journal of Agricultural Extension

Vol. 24 (2) April, 2020

ISSN(e): 24086851; ISSN(Print); 1119944X

http://journal.aesonnigeria.org

http://www.ajol.info/index.php/jae

Email: editorinchief@aesonnigeria.org

participation in marketing or resort to other means of marketing such as spot markets. The use of spot markets may not be as rewarding to the farmers as formal markets are, mainly due to traders' opportunistic behaviour. In addition, spot markets are becoming less popular in the liberalised environment. To sum up, owing to institutional aspects, smallholder farmers face difficulties in accessing formal markets. This calls for institutional development among this group of farmers.

There are farmers participating in the formal markets and others participate in the informal dairy markets due to various institutional factors (Lesotho National Development Corporation, 2017).

In the commercial agricultural economy of Lesotho, there is high demand for milk for consumption and processing especially in the formal economy. Also, there is a high number of active dairy farmers in the country but this demand is not met since farmers still participate in the informal markets instead of the milk demanding and lucrative formal markets (Bureau of Statistics, 2015). Therefore, the study will investigate the institutional factors that influence participation in formal and informal dairy markets.

\section{Purpose of the study}

The main objective of the study was to identify and assess the institutional factors influencing milk market participation amongst smallholder farmers in the Maseru urban in Lesotho, South Africa

\section{Methodology}

The study was carried out in Maseru urban area of Lesotho, South Africa. Lesotho is located between latitudes 28 and 31 and the longitudes 27 and 30 .

Dairy farmers in Maseru urban constituted the population for the study. The estimated dairy farmers' population in Maseru urban was 30 dairy farms (LDP, 2018). All the 30 dairy farmers were selected for the study. According to Zekic-Susac et al, (2016), a sample size between 30 and 500 is generally sufficient for many researches and the decision on size should reflect the quality of the sample in the wide interval. Data were collected using structured interview schedule

The statistical indicators that included frequencies and percentages were used to describe the identified milk market channels used by dairy farmers in Maseru urban. Logit Regression Model was used to analyse institutional factors that influence participation in milk markets and their effect on market participation. According to Zekic-Susac et al, (2016) logistic regression model can be used because of its ability to determine the effect of explanatory variables on the probability of the dependent variable and it yields the highest predictive accuracy possible with a given set of predictors. 
Creative Commons User License: CC BY-NC-ND

Abstracted by: EBSCOhost, Electronic Journals Service (EJS), Google Scholar, Journal Seek, Scientific Commons,

Food and Agricultural Organization (FAO), CABI and Scopus

http://eoi.citefactor.org/10.11226/v24i2
Journal of Agricultural Extension

Vol. 24 (2) April, 2020

ISSN(e): 24086851; ISSN(Print); 1119944X

http://journal.aesonnigeria.org

http://www.ajol.info/index.php/iae

Email: editorinchief@aesonnigeria.org

Table 1: Description of explanatory variables used in the model

\begin{tabular}{|c|c|c|}
\hline Variable name & Coding of variable & $\begin{array}{l}\text { Expected } \\
\text { relationship }\end{array}$ \\
\hline Market Channel & 1 formal, informal 0 & \\
\hline Market information & 1 if access, otherwise 0 & + \\
\hline Extension services & 1 if access, otherwise 0 & + \\
\hline Distance to milk markets & 1 if short, if long 0 & $+/-$ \\
\hline Member of farmer organisation & $\begin{array}{l}1 \text { if member, otherwise } \\
0\end{array}$ & + \\
\hline Availability of contracts & 1 if access, otherwise 0 & + \\
\hline Delayed payments & 1 if yes, otherwise 0 & - \\
\hline Path dependent decisions & 1 if yes, otherwise 0 & $+/-$ \\
\hline Government support & 1 if yes, otherwise & + \\
\hline $\begin{array}{l}\text { Availability of extensive social } \\
\text { capital }\end{array}$ & 1 if yes, otherwise 0 & + \\
\hline
\end{tabular}

The following model was specified for market channel choice analysis:

Market channel $=\beta_{0}+\beta_{1}$ access to market information $+\beta_{2}$ access to extension service $+\beta_{3}$ distance to milk collection centre $+\beta_{4}$ government support $+\beta_{5}$ member in farmers' organization $+\beta_{6}$ path dependency $+\beta_{7}$ delayed payments $+\beta_{8}$ contractual agreements $+\beta_{9}$ availability of social capital $+\varepsilon$ i.

\section{Results and Discussion}

\section{Market Channels Used by Dairy Farmers}

Table 2 shows that about $40 \%$ of dairy farmers use informal markets and they sell to individuals at farm gate, road side, bus stops and to local primary schools. There is gender inequity in terms of farmers who participate in the informal dairy markets as females were dominant at $60 \%$ and the explanation for this is that women are forced to supervise the activities as men go to business districts to look for jobs. The majority of farmers using the informal market channels were above the age of 60 and have been in farming for a relatively longer period and it is assumed that more experience increases knowledge about marketing systems. This knowledge may put the older and experienced farmers in a better position to choose the more rewarding markets in their contexts.

The other category of farmers $(60 \%)$ use formal milk markets and all of them sell their produce in the formal markets through mainly the Lesotho Dairy Products. They have relatively high monthly household incomes from non-farm sources and it could be argued that their household incomes enable them acquire necessary inputs, equipment and infrastructure that help them to meet formal market requirements. 
Creative Commons User License: CC BY-NC-ND

Abstracted by: EBSCOhost, Electronic Journals Service (EJS), Google Scholar, Journal Seek, Scientific Commons,

Food and Agricultural Organization (FAO), CABI and Scopus

http://eoi.citefactor.org/10.11226/v24i2
Journal of Agricultural Extension

Vol. 24 (2) April, 2020

ISSN(e): 24086851; ISSN(Print); 1119944X

http://journal.aesonnigeria.org

http://www.ajol.info/index.php/iae

Email: editorinchief@aesonnigeria.org

The dairy farmers' level of education was relatively low with an average of 4 years of formal schooling. The educational level has an influence on their ability to access, interpret, understand and use market information which can help to make informed marketing decisions. The statistics revealed that there was a negative relationship between education level and participation in the formal dairy markets with a correlation coefficient of -0.607 . Respondents with better education participate less in the formal mohair markets and these statistics can lead to a conclusion that, in Lesotho, ability to interpret information is not that important when using formal markets because government agencies and officials gather and interpret information for small-scale farmers that use such channels.

Household size ranges from a minimum of three people to a maximum of 20 persons, with a mean of 9 persons in each household across the two categories of farmers. According to Randela (2015), a larger household size has a negative effect in produce marketing because the household needs to supply household consumption before it decides to sell. Evidence from this research confirms this line of argument because larger households in this research sold less produce as compared to smaller households. The relationship between the household size and quantity of milk sold had a correlation coefficient of -0.705 .

Table 2: Demographics among dairy farmers in Maseru Urban

\begin{tabular}{llccc}
\hline $\begin{array}{l}\text { Market } \\
\text { Channel }\end{array}$ & Variable & Minimum & Maximum & Mean \\
\hline Informal (40\%) & $\begin{array}{l}\text { Non-farm } \\
\text { Income }\end{array}$ & 350.00 & 750.00 & 410.00 \\
& Age & 50 & 77 & 63 \\
& $\begin{array}{l}\text { Education } \\
\text { years }\end{array}$ & 1 & 8 & 4 \\
Formal (60\%) & Household size & 3 & 20 & 9 \\
& $\begin{array}{l}\text { Non-farm } \\
\text { Income }\end{array}$ & 750.00 & 4700.00 & 3650.00 \\
& Age & 29 & 48 & 38 \\
& $\begin{array}{l}\text { Education } \\
\text { years }\end{array}$ & 1 & 9 & 4 \\
& Household size & 3 & 20 & 9 \\
\hline
\end{tabular}

\section{Institutional Factors Influencing Participation in Milk Markets}

This section presents the results of the logistic regression model and discusses the results of the significant variables that determine market participation choices among dairy farmers in the study area. The variables that were discussed in the previous section were considered for the model and tested for their significance. The logistic regression results of are presented in Table 3. The table shows the estimated 
Creative Commons User License: CC BY-NC-ND

Abstracted by: EBSCOhost, Electronic Journals Service (EJS), Google Scholar, Journal Seek, Scientific Commons,

Food and Agricultural Organization (FAO), CABI and Scopus

http://eoi.citefactor.org/10.11226/v24i2
Journal of Agricultural Extension

Vol. 24 (2) April, 2020

ISSN(e): 24086851; ISSN(Print); 1119944X

http://journal.aesonnigeria.org

http://www.ajol.info/index.php/iae

Email: editorinchief@aesonnigeria.org

coefficients ( $\beta$ values), standard error, significance values and odd ratio of independent variables in the model.

According to Ramosacaj et al, (2015), the coefficient values measure the expected change in the logit for a unit change in each independent variable, all other independent variables being equal. The sign of the coefficient shows the direction of influence of the variable on the logit. It follows that a positive value indicates an increase in the likelihood that a household will change to the alternative option from the baseline group. On the other hand, a negative value shows that it is less likely that a household will consider the alternative (Zekic-Susac et al, 2016). Therefore, in this study, a positive value implies an increase in the likelihood of changing from participating in marketing in the formal to informal market participation choice.

The significance values (also known as p-values) show whether a change in the independent variable significantly influences the logit at a given level. In this study, the variables were tested at the $5 \%$ and $10 \%$ significance levels. Thus, if the significance value is greater than 0.05 and/or 0.10 , then it shows that there is insufficient evidence to support that the independent variables influence a change away from the baseline group. If the significance value is equal to or less than 0.05 and/or 0.10 , then there is enough evidence to support a claim presented by the coefficient value. The odds ratio indicates the extent of the effect on the dependent variable caused by the predictor variables. Its value is obtained by calculating the anti-logarithm of each slope coefficient of predictor variables. A value greater than one implies greater probability of variable influence on the logit and a value less than one indicates that the variable is less likely to influence the logit. The standard error measures the standard deviation of the error in the value of a given variable (Ramosacaj et al, 2015; Zekic-Susac et al, 2016).

Table 3: Logistic regression model results

\begin{tabular}{|c|c|c|c|c|c|c|}
\hline Variable & Coef. & Std. Err. & $\mathbf{z}$ & $P>|z|$ & [95\% Conf & Interval \\
\hline Mktinfo & 2.659982 & 1.53215 & 1.74 & $0.083^{*}$ & 0.3429761 & 5.66294 \\
\hline Extserv & 0.6642027 & 1.580651 & 0.42 & 0.674 & -2.433817 & 3.762223 \\
\hline Mktdistance & 0.6435231 & 0.3351661 & 1.92 & $0.055^{\star}$ & 0.0133904 & 1.300437 \\
\hline Mbof & 2.116855 & 1.239205 & 1.71 & $0.088^{*}$ & $\overline{0} .3119425$ & 4.545652 \\
\hline Delpay & 2.6599723 & 1.53215 & 1.73 & $0.084^{*}$ & 0.3429761 & 5.652945 \\
\hline $\begin{array}{l}\text { Govsupp } \\
\text { Contract } \\
\text { Pathdep }\end{array}$ & $\begin{array}{l}4.114859 \\
4.068107 \\
4.116279\end{array}$ & $\begin{array}{l}1.957674 \\
1.401376 \\
1.868748\end{array}$ & $\begin{array}{l}2.10 \\
1.78 \\
2.10\end{array}$ & $\begin{array}{l}0.036^{* *} \\
0.034^{* *} \\
0.043^{* *}\end{array}$ & $\begin{array}{l}0.2778822 \\
0.2873468 \\
0.2789731\end{array}$ & $\begin{array}{l}7.951825 \\
0.598467 \\
7.856315\end{array}$ \\
\hline Socialcap & 4.2765432 & 1.755438 & 1.87 & $0.036^{* *}$ & 0.2543876 & 7.906843 \\
\hline
\end{tabular}


Creative Commons User License: CC BY-NC-ND

Abstracted by: EBSCOhost, Electronic Journals Service (EJS), Google Scholar, Journal Seek, Scientific Commons,

Food and Agricultural Organization (FAO), CABI and Scopus
Journal of Agricultural Extension

Vol. 24 (2) April, 2020

ISSN(e): 24086851; ISSN(Print); 1119944X

http://journal.aesonnigeria.org

http://www.ajol.info/index.php/iae

Email: editorinchief@aesonnigeria.org

Access to Market information: access to market information has the $p$-value of 0.083 which is significant at $10 \%$ with a positive effect on formal market participation. This significance value implies that there is enough evidence to support that an increase in the availability of market information results in an increase in formal market participation. The result agrees with a priori expectation that farmers with access to market information on demand, prices, quality standards and returns on different markets participate in formal markets because they are better informed and approach their production and marketing activities accordingly. The results are consistent with Djalalou et al., (2012) who suggest that access to timely, accurate and up-to-date market information is fundamental for commodity marketing in formal markets.

Access to Extension Services: the results showed that access to extension service was insignificant with a p-value of 0.674 thus it does not influence marketing decisions. The significance value implies that there is not enough evidence to support that extension services influence market participation among dairy farmers in Maseru. The results do not agree with the study's a priori expectation that extension services enhance dairy farmers' skills and knowledge through provision of information on proper management practices and link them with modern technology which will increase their chances to participating in the formal markets. The possible explanation for this may be that extension officers do not attend to all groups of farmers participating either formally or informally and are not able to monitor if their advices have been implemented due to large population of farmers. This is a result of high farmer to extension agent ratio as Makapela (2015) stated that there is limited access to extension in most cases with the extension staff to farmer ratio standing at 1: 1500 approximately.

Distance to milk collection centres: distance to milk collection centre has a positive and significant influence on participation in the informal markets with a pvalue of 0.05 which implies that an increase in distance to milk collection centers or markets resulted in an increase in the degree of informal market participation. The more the distance to milk collection centers the higher the chances of participating in the informal markets than in the formal markets. The explanation for this scenario is that farmers are likely to participate in the informal market in order to avoid incurring transaction costs associated with organising and coordinating transport for moving milk to usually distant collection centres. The findings agree with Terefe (2016) that the more the market is close to the farmers' dwellings the higher chances of participating in such markets in order to avoid transportation and transaction costs.

Membership in farmer organization: membership in a farmer organisation positively influences participation in the formal milk markets with a p-value of 0.088 and significant at $10 \%$ level. This means that there is enough evidence to support than an increase in the level of membership in farmer organisations increases participation in the formal milk markets. The result is consistent with the study's a priori expectation that a farmer who belongs a farmer organization is more likely to participate in formal markets. The result means that if a farmer is involved in the farmers' organization there are high chances of participating in the formal market 
Creative Commons User License: CC BY-NC-ND

Abstracted by: EBSCOhost, Electronic Journals Service (EJS), Google Scholar, Journal Seek, Scientific Commons,

Food and Agricultural Organization (FAO), CABI and Scopus
Journal of Agricultural Extension

Vol. 24 (2) April, 2020

ISSN(e): 24086851; ISSN(Print); 1119944X

http://journal.aesonnigeria.org

http://www.ajol.info/index.php/iae

Email: editorinchief@aesonnigeria.org

http://eoi.citefactor.org/10.11226/v24i2

because they share market and production information and have better contacts that link them to the formal markets and there is collective action which enables farmers to attain bargaining power, economies of scale and reduced transaction costs. Pelimina and Urassa (2015) indicated that farmer organizations provide some technical assistance and trainings to members in order to improve their marketing information and reduced transaction cost through buying inputs and marketing their produce in groups. The group participation helps the farmers to meet the stringent requirements that characterise the formal markets.

Delayed payments: this variable has a negative and significant relationship with the dairy farmers' participation in the formal markets and has a p-value of 0.084 significant at $10 \%$ level. This implies that there is enough evidence to support that an increase in delayed payments decreases dairy farmers' participation in the formal milk markets. The odd ratio suggests that there is a probability of shifting from the formal to the informal marketing with an increase in delayed payments. The result is consistent with the study's a priori expectation that delayed payments are likely to discourage farmers from participating in a particular market. Due to the perennial delays in the payments from Lesotho Dairy Products, dairy farmers have to approach buyers several times in order to get paid and the monitoring related transaction costs are increased for the farmers. This dissatisfies the farmers and some leave the formal market for the informal markets that are characterised by prompt payments. The results agree with Rantlo (2018) that the dissatisfaction of smallholder farmers in some markets led to their shifting to alternative output markets.

Government support: this variable positively influences dairy farmers' participation in the formal markets and has a p-value of 0.036 . This $p$-value implies that there is enough evidence that an increase in government support to the dairy farmers influences participation in the formal milk markets in the study area. This finding is consistent with conventional expectation that government support enhances participation in the formal markets than in the informal markets. Most farmers participate formally because of government support in the form of subsidised inputs, free technical advisory services and granting of improved technologies. This support enables farmers that use formal markets to meet standards and grades required by the formal markets. This is supported by Kihoro (2016) when indicating that Government support encourages farmers to participate in the formal markets as farmers are capacitated to improve quantity and quality of output/produce necessary to participate in formal markets.

Path dependency: this variable has a positive and significant relationship with dairy farmers' participation in the informal market with a $p$-value of 0.043 . This $p$-value means that there is enough evidence that an increase in the level of path dependency increases participation in the informal milk markets. These dairy farmers' decision making is influenced by what their forefathers have been doing as they follow what their elders have been doing in their dairy businesses. The smallholders that use formal markets are characterised by path dependency which determines the action situation in the dairy industry in the country as it reflects that 
Creative Commons User License: CC BY-NC-ND

Abstracted by: EBSCOhost, Electronic Journals Service (EJS), Google Scholar, Journal Seek, Scientific Commons,

Food and Agricultural Organization (FAO), CABI and Scopus
Journal of Agricultural Extension

Vol. 24 (2) April, 2020

ISSN(e): 24086851; ISSN(Print); 1119944X

http://journal.aesonnigeria.org

http://www.ajol.info/index.php/iae

Email: editorinchief@aesonnigeria.org

information and knowledge are shared among participants and between generations.

This attribute influences marketing choices as these smallholders chose informal markets because they have been used and trusted by their forefathers. These smallholders continue to participate in the informal markets because, according to them, these informal mohair markets offer more benefits and changing to the alternative markets will impose immediate and high costs on their dairy farming business. From an economic point of view, the cost-benefit analysis by these smallholder mohair farmer's favours participation in the informal mohair markets. These findings agree with those of Rantlo (2018) that path dependency and cost benefit analysis are some of the factors that influence marketing decisions among small-scale farmers.

Availability of contractual agreements: a positive and significant relationship was found between this variable and participation in the formal dairy markets. The $p$ value for the relationship is 0.034 which implies that there is enough evidence that an increase in the prevalence of contractual agreements influences dairy farmers' participation in the formal milk markets. This agrees with the study's a priori expectation that farmers with contractual agreements with buyers are more likely to participate in formal markets. Contractual agreements facilitate and enhance communication, hence information flow between dairy farmers and buyers which results in incentives that influence economic behaviour and decision making among small-scale farmers. The contractual agreements provide guaranteed access to formal markets as it enables the exchange partners to know the preferences and expectations of each other in terms of quality, in particular. The dairy farmers meet the quality requirements of the buyers as a result, which in turn reduces costs associated as the exchange costs (information search and negotiations) are reduced for small-scale farmers and for buyers. The contractual agreements render participation in the formal markets less costly and more beneficial to this group of smallholders, hence use of such markets. This is supported by Ramoroka (2012) when stating that contractual agreements facilitate smallholder farmers' participation in the formal output markets.

Availability of social capital: the positive and significant relationship was found between social networks and farmers' participation in the informal milk markets and achieved a p-value of 0.036 . This value implies that there is enough evidence that an increase in the prevalence of social capital influences farmers to participate in the informal milk markets in Maseru. These informal institutions facilitate the sharing of information between the dairy farmers that use informal milk markets. One of the results of these interactions is the knowledge of milk prices offered by informal buyers prior to the time of milk sales. The prior knowledge of mohair price positively influences the transaction costs incurred by small-scale mohair farmers in the informal markets because it affords the smallholders a chance to select the informal buyer or trader that offer better prices thus avoiding the cost of missing out on a relatively higher net income. In the formal markets, where the prices are only known at the time of sale, the farmers do not get an opportunity to look for buyers who offer better prices (when offered prices are unfavourable). These results agree with 
Creative Commons User License: CC BY-NC-ND

Abstracted by: EBSCOhost, Electronic Journals Service (EJS), Google Scholar, Journal Seek, Scientific Commons,

Food and Agricultural Organization (FAO), CABI and Scopus

http://eoi.citefactor.org/10.11226/v24i2
Journal of Agricultural Extension

Vol. 24 (2) April, 2020

ISSN(e): 24086851; ISSN(Print); 1119944X

http://journal.aesonnigeria.org

http://www.ajol.info/index.php/jae

Email: editorinchief@aesonnigeria.org

Rafoneke and Rantlo (2016) that social networks play a critical role in the marketing decision making among smallholder farmers in rural Lesotho.

\section{Conclusion and Recommendations}

Most smallholder dairy farmers used the formal milk markets while minority preferred the informal milk markets in Maseru, Lesotho.

Due to access to market information, the dairy farmers' ability to meet grades and standards required by the buyers in the formal markets is improved hence participation in the formal milk markets.

Government support in the form of free technical advice, subsidised inputs, infrastructure and technologies has created an environment that is conducive for the participation of dairy farmers in the formal milk markets.

Collective action through membership in farmer organisations reduces barriers that prevent the small-scale dairy farmers from participating in the lucrative formal markets. The contractual agreements render the formal market a guaranteed market for the small-scale dairy farmers and enhance their participation in the formal milk markets

Social networks influence and consolidate their participation in the informal markets to the detriment of the integration into the formal milk markets.

The long distance between their dwellings and formal markets is associated with high costs which led to them opting for and participating in the usually closely located informal milk markets.

The participation of this category of scale dairy farmers in the informal markets is significantly enhanced by their path dependent decision making. In addition, their participation in the formal milk markets is limited and threatened by high monitoring transaction costs associated with delayed payments that characterise the formal markets.

In order to address the challenge of delayed payments and associated transaction costs, it is recommended that advance payment be introduced where a certain portion of the agreed milk price can be paid upfront to the farmers. This financial arrangement can help the dairy farmers who sell in the formal markets to meet the daily and current obligations of their enterprises.

The support system should be developed to ensure that dairy farmers in the informal markets receive various forms of support from the government of Lesotho and development partners as is the case with the farmers in the formal markets. This will ensure that such farmers are able to withstand the business rigours and stringent requirements in the markets. In addition, it is recommended that milk collection centers be decentralised and established in the areas where there is meaningful 
Creative Commons User License: CC BY-NC-ND

Abstracted by: EBSCOhost, Electronic Journals Service (EJS), Google Scholar, Journal Seek, Scientific Commons,

Food and Agricultural Organization (FAO), CABI and Scopus

http://eoi.citefactor.org/10.11226/v24i2
Journal of Agricultural Extension

Vol. 24 (2) April, 2020

ISSN(e): 24086851; ISSN(Print); 1119944X

http://journal.aesonnigeria.org

http://www.ajol.info/index.php/jae

Email: editorinchief@aesonnigeria.org

concentration of dairy farmers and milk production in order to facilitate and enhance participation of the farmers in the lucrative milk markets.

\section{References}

Bairwa, S. L. Singh, R. Kushwaha, S. Kamalvanshi, S. and Lokesh, S. M., (2014). Economic analysis of marketing margin of milk and milk products: A study of Jaipur Dairy Cooperative. Annals of Agri-Bio Research, 19 (2):321-325

Bureau of Statistics (2015). The contribution of agriculture and manufacturing sectors towards economic development of Lesotho. Report. Government Printing, Maseru

Djalalou, D.A.A., Stefano,P., Anita, R.L.,Ousmane,C.,Geoffrey, H., and Onno, S.F.W.O,(2012). Market channel participation of smallholder Pineapple farmers in Benin. Las Vegas international academy conference, Nevada USA

Ferris, S. Robbins, P. Best, R. Seville, D. Buxton, A. Shriver, J and Wei, E., (2014). Linking Smallholder Farmers to Markets and the Implications for Extension and Advisory Services. MEAS discussion paper No. 4. United States Agency for International Development, Michigan

Goodwin, J. N and Gouldthorpe, L. J., (2014). "Small' 'Farmers, big challenges: A needs assessment of Florida small-scale farmers' production challenges and Training needs. Journal of Rural Social Sciences 28(1):54-79

Jagwe, J.N., (2012). The Impact of Transaction Costs on the Participation of Smallholder Farmers and Intermediaries in the Banana Markets of Burundi, Democratic Republic of Congo and Rwanda. PhD Thesis. University of Pretoria, RSA.

Kihoro, E., (2016). An Analysis of Factors Influencing Farmers' Choice of green gram Marketing Channels in Meere south sub-county, Kenya. MSc. Thesis, Department of Agricultural Economics. University of Nairobi, Kenya

Lesotho Dairy Products (2018). Quarterly Review. Maseru, Lesotho.

Lesotho National Development Corporation (2017). Annual Business Report. Maseru, Lesotho.

Makapela, M. (2015). Effectiveness of Agricultural Extension Organisation in rural areas. M.Sc. Thesis, University of South Africa, Eastern cape.

Ministry of Agriculture and Food Security. (2016). Agricultural Production and Marketing Report. Ministry of Agriculture and Food Security. Masseru, Lesotho.

Moturi, O. W, Gideon, A. O and Alexander, K. K. (2015). Milk marketing channel choices for enhanced competitiveness in The Kenya Dairy Supply Chain: A multinomial Logit Approach. International conference of Agricultural economists

Pelimina, B. M and Urassa, J. (2015). The contribution of farmers' organisations to smallholder farmers' well-being: A case study of Kasulu district, Tanzania. African Journal of Agricultural Research, 10(23):2343-2349 
Creative Commons User License: CC BY-NC-ND

Abstracted by: EBSCOhost, Electronic Journals Service (EJS), Google Scholar, Journal Seek, Scientific Commons,

Food and Agricultural Organization (FAO), CABI and Scopus

http://eoi.citefactor.org/10.11226/v24i2
Journal of Agricultural Extension

Vol. 24 (2) April, 2020

ISSN(e): 24086851; ISSN(Print); 1119944X

http://journal.aesonnigeria.org

http://www.ajol.info/index.php/jae

Email: editorinchief@aesonnigeria.org

Rafoneke, L and Rantlo A., M. (2016). The institutional and technical constraints to peach marketing in Lesotho. International Journal of Recent Advances in Multidisciplinary Research, 3(8), 1795-1801.

Ramoroka, H. K. (2012). Participation and utilisation of formal vegetable markets by smallholder farmers in Limpopo: A tobit ii approach. MSc. Thesis, University of Limpopo, South Africa.

Ramosacaj. M . Hasani, V and Dumi, A. (2015). Application of logistic regression in the study of students' performance level (case of Vlora University). Journal of Educational and Social Research, 5(3):239-244

Randela, R., 2015. Integration of Emerging Cotton Farmers into the Commercial Agricultural Economy. PhD Thesis, University of Free State, RSA.

Rantlo. A. M. (2018). Integration of small-scale mohair farmers into the commercial agricultural economy in Lesotho: A new institutional economics approach. PhD thesis, Rhodes University. Grahamstown, South Africa.

Sekoai, T. and Rantlo, A.M. (2016). Analysis of institutional constraints to peach production in Butha- Buthe. International Journal of Information Research and Review.Vol. 03( 08) pp. 2647-2652.

'Terefe, B.(2016). Key Factors Affecting Market Participation of Small Dairy Farmers: $\quad$ the Case of Bako Tibe District, West Showa Zone, Oromia, Ethiopia. Paper for presentation at the 14th International Conference on the Ethiopian Economy. Ethiopian Economic Association (EEA) Conference Centre, Addis Ababa, Ethiopia.

Zekic-Susac. M. Sarlija, N. Has, A and Bilandzic, A. (2016). Predicting company growth using logistic regression and neural networks. Croatian Operational Research Review, $7: 229-248$ 